\title{
EL ÉXITO EMPRESARIAL DE PEQUEÑAS Y MEDIANAS EMPRESAS AGROINDUSTRIALES EN EL DEPARTAMEN- TO LA CAPITAL (SANTA FE, ARGENTINA)
}

\author{
Malano, D. L. ${ }^{1}$; Sandoval, P. ${ }^{2}$; Ansaldo, N. V. ${ }^{1}$ \& Garramuño, S. ${ }^{1}$
}

\begin{abstract}
RESUMEN
En esta investigación se debatirán los factores que influyen en el resultado de las empresas relacionadas con el sector agropecuario, más allá de los aspectos puramente cuantitativos. A partir de esta concepción, se han tomado como eje de análisis los aspectos personales del empresario, para lo cual, se realizó un estudio de casos de empresarios de Pequeñas y Medianas Empresas (Pymes) del sector agroindustrial, para comprender cuáles son los factores relevantes o significativos en el éxito empresarial, abordados y analizados desde sus historias personales, considerando sus representaciones mentales, motivaciones, conceptualizaciones y conductas que adoptan frente a la toma de decisión empresarial. Se aplicó una metodología de investigación de índole cualitativa con triangulación de técnicas, cruzando los datos obtenidos de entrevistas en profundidad, observación participante y encuesta estructurada. Los resultados obtenidos indican la presencia de tres factores relevantes, como son: la capacidad de gestión, la relación de pertenencia y el aprendizaje adaptativo.

Palabras claves: éxito empresarial, empresario, pequeñas y medianas empresas, historia personal, complejidad.
\end{abstract}

\section{SUMMARY}

The management success of small and medium companies agroindustrials in the department the capital (Santa Fe, Argentina).

In this investigation you to debate the factors that influence in the result of the companies related to the agroindustrial sector, beyond the purely quantitative aspects. Starting from this conception, there is taking as analysis axis the manager's personal aspects, for that which, was carried out a study of manager's cases SME's of the agroindustrial sector, to understand which the outstanding or significant factors are in the management success approached and analyzed from their personal histories, considering their mental representations, motivations, conceptualizations and behaviors that they adopt in front of the management take of resolution. For that, a methodology of investigation of qualitative nature was applied with triangulation technical, crossing the obtained data from depth interviews, participant observation and structured interviews. The obtained results indicate the presence of three outstanding factors, as such: the administration capacity, the relation of ownership and the adapted learning.

Key words: management success, SME's Manager, SME's, personal history, complexity.

1.- Facultad de Ciencias Veterinarias, Universidad Nacional del Litoral. Kreder 2805, Esperanza, provincia de Santa Fe.

2.- Facultad de Ciencias Agrarias, Universidad Nacional del Litoral.

Manuscrito recibido el 10 de julio de 2004 y aceptado para su publicación el 11 de mayo de 2005. 